Vol.1 No.1 Januari 2018

ISSN 2614-2775

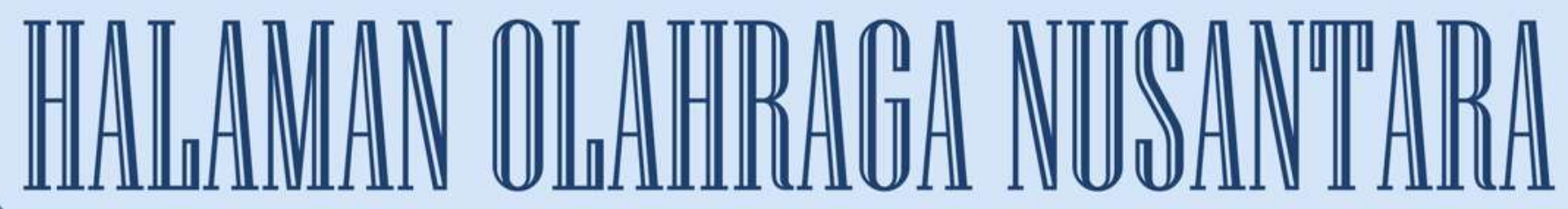

Curnal \&lmu Q Xeolahragaan

Diterbitkan Oleh:

Program Studi Pendidikan Olahraga

Pakultas Keguruan dan Ilmu Pendidikan

Universitas PGRI Palembang

\begin{tabular}{|c|c|c|c|c|c|}
\hline Jurnal & Volume & Nomor & Halaman & Palembang & ISSN \\
\hline IItaman Oahraya Vissantara & 1 & 1 & $1 \cdot 132$ & 2018 & 2014.27175 \\
\hline
\end{tabular}


Artikel Ilmiah

Perbedaan Variasi Latihan Juggling dan Rasio Koordinasi Mata-Kaki terhadap Hasil Kontrol Bola dari Tendangan Jarak Jauh Sepak Bola Hengki Kumbara

Hubungan Antara Kekuatan Otot Tungkai dan Kekuatan Otot Lengan terhadap Hasil Kecepatan Renang 50 Meter Gaya Bebas pada Atlet Putri Club Bangka Swimming

Farizal Imansyah

Motivasi Mahasiswa PGSD dalam Olahraga Rekreasi di Water Fun Kota Palembang

M. TaheriAkikbar

Pengaruh Metode Sirkuit terhadap Kemampuan Teknik Dasar Sepakbola pada Kegiatan Ekstrakurikuler Siswa SMAN 5 Kabupaten Tebo Alek Oktadinata

Kontribusi. Daya Ledak Otot Thung:kai dan Kelentukan dengan [1asil] Lompat Tinggi Gaya Flop Mahasiswa Program Studi Pendidikan Olahraga Universitas PG:RIPalembang IIham Arvan Junaidi

Kemampuan Meng.gining Bola (IStudi Korelasional Kecepatan ( $\left.x_{1}\right)$ dan Kelineahan $\left(x_{2}\right)$ dengan Kemampuan Dribel pada Permainan Sepabola Siswa Sekolah Menengah Pertama) Putwi Cicilla Kristina

Revitalisasi Masyarakat ¿iban/Perkotaan Melalui Olahraga Petanque Arcdo okilanda

Peranan Mata Pelajaran Pendidikan Jasmani dalam Meningkatkan Kesadaran Kesehatan \$iswa đi Lingkungan \$ekolah Dasar

Negeri nur Tegalkalong Kabupaten sumedang

№ Siti nurfaeni Sofa dan Anggi Setia Lengkana

Peran Motor Educability di dalam Meningkatan Keterampilan Olahraga pada Pembelajaran Penjas

gieru Syarili Lesmana

MơtivasiAnggota Pusat Kebugaran dalam Mengikuti Latihan Fitness padaKota Sekaycu Sugar Wanto

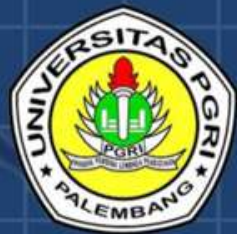

Program Studi Pendidikan Olahraga Fakultas Keguruan dan Ilmu Pendidikan Universitas PGRI Palembang 
ISSN 2614-2775

\section{HALAMAN OLAHRAGA NUSANTARA}

Jurnal Ilmu Keolahragaan

Volume 1, Nomor 1, Januari 2018

Pelindung/Penasehat

Dr. H. Bukman Lian, M. M., M. Si.

Penanggung Jawab

Dr. Dessy Wardiah, M. Pd.

Ketua Dewan Redaksi

Drs. M. Nirwan, M. Pd.

\section{Wakil Ketua Dewan Redaksi}

Ilham Arvan Junaidi, M. Pd.

\section{Sekretaris}

Nasrullah, M. Pd.

Penyunting Pelaksana

Rafel Orlando, M. Pd

Ardo Okilanda, M. Pd

\section{Penyunting Ahli/ Mitra Bestari}

Prof. Dr. A. Sofyan Hanif, M. Pd (Universitas Negeri Jakarta)

Dr. Ronni Yenes, M. Pd (Universitas Negeri Padang)

Dr. Putri Cicilia Kristina, M. Pd (Universitas PGRI Palembang)

\section{Tata Usaha}

M. Taheri Akbar, M. Pd

\section{Setting:}

Dede Dwiansyah Putra, M. Pd

Alamat Redaksi:

Prodi Pendidkan Olahraga Fakultas Keguruan Ilmu dan Pendidikan Universitas PGRI Palembang

Jl. Jendral A. Yani Lorong Gotong Royong 9/10 Ulu Palembang Telp. 0711-510043, Fax. 0711-514782

e-mail jurnal: rafelorlando333@gmail.com

e-mail : ardo.oku@ univpgri-palembang.ac.id

website: univpgri-palembang.ac.id 


\section{DAFTAR ISI}

Perbedaan Variasi Latihan Juggling dan Rasio Koordinasi Mata-Kaki terhadap Hasil Kontrol Bola dari Tendangan Jarak Jauh Sepak Bola

Hubungan Antara Kekuatan Otot Tungkai dan Kekuatan Otot Lengan terhadap Hasil Kecepatan Renang 50 Meter Gaya Bebas pada Atlet Putri Club Bangka Swimming

- Farizal Imansyah

Motivasi Mahasiswa PGSD dalam Olahraga Rekreasi di Water Fun Kota Palembang

- $\quad$ M. Taheri Akhbar

Pengaruh Metode Sirkuit terhadap Kemampuan Teknik Dasar Sepakbola pada Kegiatan Ekstrakurikuler Siswa SMAN 5 Kabupaten Tebo

- Alek Oktadinata

Kontribusi Daya Ledak Otot Tungkai dan Kelentukan dengan Hasil Lompat Tinggi Gaya Flop Mahasiswa Program Studi Pendidikan Olahraga Universitas PGRI Palembang

- Ilham Arvan Junaidi

Kemampuan Menggiring Bola (Studi Korelasional Kecepatan $\left(\mathrm{x}_{1}\right)$ dan Kelincahan $\left(\mathrm{x}_{2}\right)$ dengan Kemampuan Dribel pada Permainan Sepabola Siswa Sekolah Menengah Pertama)

- Putri Cicilia Kristina

Revitalisasi Masyarakat Urban/Perkotaan Melalui Olahraga Petanque

- $\quad$ Ardo okilanda

Peranan Mata Pelajaran Pendidikan Jasmani dalam Meningkatkan

Kesadaran Kesehatan Siswa di Lingkungan Sekolah Dasar

Negeri III Tegalkalong Kabupaten Sumedang

- $\quad$ N. Siti nur'aeni Sofa dan Anggi Setia Lengkana

Peran Motor Educability di dalam Meningkatan Keterampilan

Olahraga pada Pembelajaran Penjas

- Heru Syarli Lesmana 
Motivasi Anggota Pusat Kebugaran dalam Mengikuti Latihan Fitness pada Kota Sekayu

Sugar Wanto 


\title{
REVITALISASI MASYARAKAT URBAN/PERKOTAAN MELALUI OLAHRAGA PETANQUE
}

\author{
Oleh: Ardo Okilanda \\ (Dosen Universitas PGRI Palembang)
}

\begin{abstract}
Abstrak
Kehidupan di Indonesia, kita mengenal masyarakat desa dan kota yang merupakan bentuk berbeda dari gambaran masyarakat Indonesia. Biasa kita sebut masyarakat urban/perkotaan (daerah perkotaan). Kelompok masyarakat urban/perkotaan pada banyak kehidupan lebih sering dalam keadaan yang bisa dikatakan jauh dari bermasyarakat, Manusia bukan hanya sekedar jasmani yang nampak pada umumnya secara kasat mata, namun juga memiliki spirit di dalam dirinya. Hal ini seringkali disebut dengan body, mind, dan soul. Maka dari itu yang akan menjadi bagian penting dalam aspek Revitalisasi kali ini adalah komunikasi dalam kehidupan masyarakat urban/perkotaan. Pada abad pertengahan, permainan Petanque telah dimainkan diseluruh eropa dikenal dengan sebutan boules. Pada abad ke-14, Raja Henri III dari Inggris, Raja Charles IV dan V melarang permainan Boules dan digantikan dengan bermain panah. Petanque adalah olahraga yang diputar secara bertiga (triple) tetapi dapat juga dimainkan secara individu (single) atau berdua (double). Petanque adalah olahraga baru bagi Indonesia yang dipertandingkan di SEA GAMES XXVI/2011 di Palembang, Indonesia. Terbentuknya Federasi Olahraga Petanque Indonesia pada tanggal 18 Maret 2011. Berdirinya Venue Petanque di komplek olahraga Jakabaring yang representatif sebagai pusat pelatihan dan pembinaan. Pemanfaatan aset Petanque pasca SEA GAMES. Sehingga pada pemikiran penulis kali ini penting sekali melakukan revitalisasi pola kehidupan daripada masyarakat urban/ perkotaan dengan olahraga petanque, menjadi semacam perubahan yang harus didukung oleh lingkungan masyarakat sekitar di komplek polygon Palembang. Olahraga petanque merupakan salah satu media yang efektif didalam revitalisasi komunikasi masyarakat urban/perkotaan/ perkotaan, hal ini dikarenakan karakteristiknya yang umum dan juga dapat dijadikan kegiatan yang rutin.
\end{abstract}

Kata Kunci: Masyarakat Urban, Revitalisasi, Olahraga Petanque

\section{REVITALIZATION OF URBAN SOCIETY THROUGH PETANQUE SPORTS}

\begin{abstract}
In Indonesian, we recognize rural and urban communities which are a different form of Indonesian society. Usually we call urban / urban community (urban area). Urban / urban community groups in many lives are more often in a state that
\end{abstract}


can be said far from society, Man is not only a visible body in general, but also has a spirit within him. This is often called body, mind, and soul. Therefore, what will be an important part in this revitalization aspect is communication in urban / urban life. In medieval times, the Petanque game has been played throughout Europe known as boules. In the 14th century, King Henri III of England, King Charles IV and V banned the game of Boules and was replaced by playing arrows. Petanque is a tripleplayed sport but can also be played individually (single) or double (double). Petanque is a new sport for Indonesia that was competed in SEA GAMES XXVI/2011 in Palembang, Indonesia. Formation of Petanque Indonesia Sports Federation on March 18, 2011. The establishment of Venue Petanque in Jakabaring sports complex is representative as a training and coaching center. Utilization of Petanque assets post SEA GAMES. So at the author's thought this time it is important to revitalize the pattern of life rather than urban / urban communities with petanque sport, into a kind of change that must be supported by the surrounding community in the complex of polygon Palembang. Petanque sport is one of the effective media in revitalizing urban / urban / urban communications, this is because of its general characteristics and also can be used as routine activity.

Keywords: Urban Society, Revitalization, Sports Petanque

\section{A. PENDAhuluan}

Indonesia merupakan negara yang sedang berkembang dalam segi ekonomi masyarakat, dalam perkembangannya kehidupan itu secara tidak langsung akan dipisahkan oleh keadaan dengan yang biasa disebut kaya dan miskin. Begitu kita melihat kedalam kehidupan dan keseharian dari masyarakat ini akan sangat bertolak belakang pad acara dan taraf hidupnya. Paling penting menjadi sebuah perhatian adalah ketika terjadi kesenjangan yang sangat jauh di kehidupan yang berada pada taraf hidup yang sama.

Biasa kita sebut masyarakat urban/perkotaan (daerah perkotaan). Kelompok masyarakat urban/perkotaan pada banyak kehidupan lebih sering dalam keadaan yang bisa dikatakan jauh dari bermasyarakat, kita bisa katakan demikian karena pada kenyataannya mereka hidup dengan urusan kehidupannya sendiri. Sehingga kehidupan antar manusia yang terjadi sangat kurang. Misalkan beberapa kasus yang terjadi di masyarakat urban/perkotaan beberapa tahun lalu di komplek pulomas ketika terjadi pembunuhan satu keluarga, sampai pada 
tetangga tidak mengetahui hal yang terjadi setelah berhari-hari. Semua ini dianggap karena memang kepedulian antar lingkungan sekitar yang memang kita lihat kurang. Dengan demikian kita harus sadar bahwa beberapa hal yang sebenarnya memang harus kita ubah dari cara kehidupan seperti ini adalah dengan beberapa tindakan yang salah satunya akan kita laksanakan dengan kegiatan olahraga.

Berdasarkan hasil pengamatan yang dapat kita lihat secara jelas adalah ketika masuk ke dalam daerah masyarakat urban/perkotaan adalah tembok yang terbentang tinggi. Ketika dikunjungi sering sekali tidak berada dirumah atau bahkan malas untuk menerima tamu yang datang sebagaimama banyak terjadi pada kenyataannya. Ketika sudah sangat meresahkan semua yang ada pada masyarakat seperti ini kita jelas sebagai orang yang peduli terhadap kehidupan social ini harus memberikan bentuk perubahan cara kehidupan masyarakat untuk yang lebih baik sehingga tercapainya kerukunan masyarakat yang harmonis yang bisa saling mengenal satu sama lainnya dan bisa berbagi banyak hal. Manusia bukan hanya sekedar jasmani yang nampak pada umumnya secara kasat mata, namun juga memiliki spirit di dalam dirinya. Hal ini seringkali disebut dengan body, mind, dan soul. Manusia memiliki raga, pikiran, dan jiwa. Seiring dengan berkembangnya ilmu pengetahuan, semakin diketahui berbagai hubungan antara ketiganya yang saling berkaitan dan mempengaruhi. Kondisi kejiwaan akan mempengaruhi fisiologis dan sikap seseoran, begitu juga sebaliknya. Hukum ini sudah tidak bisa terelakkan lagi bahkan dalam kehidupan bermasyarakat. Ranah psikologis yang seringkali mendapat sorotan akan kebermanfaatannya terhadap kehidupan sosial, dulu sering dipertanyakan, namun saat ini sudah semakin dirasakan manfaatnya. Bahkan terdapat sub disiplin ilmu bermasyarakat yang secara khusus membahas psikologi sosial.

Komunikasi menjadikan semua ini sebagai alat yang bisa mempererat hubungan sesama makhluk hidup dalam bermasyarakat. Banyak orang tidak menyadari bahwa masalah-masalah yang dihadapi sebenarnya berasal dari 
komunikasi yang kurang baik. Salah satu yang menyebabkan timbulnya komunikasi tidak baik adalah karena komunikasi dengan diri sendiri tidak lancar atau bahkan tidak pernah diperhatikan (Meyer, 2015). Bagaimanapun juga, komunikasi dengan orang lain merupakan hal penting karena dapat menggali potensi diri untuk terus bisa berada baik tepat ditengah lingkungan kehidupan perkotaan yang bisa dikatakan memiliki tingkat kepedulian yang cukup rendah. Semua ini akan bisa terjadi ketika berada pada kondisi yang menyediakan kebahagiaan dan area tempat berkumpul yang bisa menyediakan ruang beberapa orang.

Sarana dan prasarana olahraga merupakan tempat yang sangat representative untuk kehidupan masyarakat urban/perkotaan memperbaiki kondisi kehidupan sosialnya dengan orang lain baik itu dengan tetangga ataupun lingkungan sekitar lainnya. Menurut Undang-Undang Republik Indonesia Tentang Sistem Keolahragaan Nasional yakni terdapat pada BAB VI Pasal 17, tentang ruang lingkup olahraga yang meliputi "olahraga pendidikan, olahraga rekreasi, dan olahraga prestasi”. Olahraga rekreasi dapat mencakup ketiga ruang lingkup olahraga tersebut. antara Permainan dan Olahraga rekreasi yang mempunyai kesamaan diantaranya keduanya sama-sama mengajarkan/melatih motorik (gerak) yang serasi dan terampil, serta dapat mewujudkan dan membentuk manusia seutuhnya dengan nilai-nilai yang terkandung di dalam aktivitasnya atau sering disebut pendidikan karakter. Terlebih bisa dilaksanakannya komunikasi di masyarakat untuk saling mempererat hubungan baik dengan lingkungan sekitarnya. akibat yang ditimbulkanya seperti rasa senang, maka dapat dijadikan sebagai penawar dari rutinitas aktivitas sehari-hari masayarakat urban/perkotaan, dengan harapan dapat meminimalis rasa jenuh/bosan masyarakat dan mempererat hubungan sosial. Dengan adanya jenis olahraga yang bersifat rekreasi, oleh karena itu kiranya setiap masyarakat perkotaan dapat lagi membangun pola hidup sosialis. Olahraga rekreasi seperti petanque merupakan salah satu olahraga yang cocok dilakukan didaerah 
perkotaan, hal ini dikarenakan karakteristik olahraganya yang mudah dan dapat dilakukan ditempat umum. Revitalisasi komunikasi masyarakat urban/perkotaan melalui olahraga kiranya merupakan hal yang perlu dilakukan juga bisa dijadikan sebagai olahraga umum dalam hal ini sebagai awal menuju pembentukkan untuk menuju daerah perkotaan yang sosialis dan sehat, karena salah satu manfaat dari aktivitas pengenalan olahraga petanque pada masyarakat akan mempunyai pengalaman-pengalaman gerak biomotor seperti kebugaran jasmani, kelincahan, daya tahan, kelentukan, kekuatan, keseimbangan dan juga membangun jiwa komunikasi.

\section{B. PEMBAHASAN}

\section{Revitalisasi}

Dalam Kamus Besar Bahasa Indonesia, revitalisasi berarti proses, cara, dan perbuatan menghidupkan kembali suatu hal yang sebelumnya kurang terberdaya. Sebenarnya revitalisasi berarti menjadikan sesuatu atau perbuatan menjadi vital. Sedangkan kata vital mempunyai arti sangat penting atau perlu sekali (untuk kehidupan dan sebagainya). Pengertian melalui bahasa lainnya revitalisasi bisa berarti proses, cara, dan atau perbuatan untuk menghidupkan atau menggiatkan kembali berbagai program kegiatan apapun (KBBI, 2005). Atau lebih jelas revitalisasi itu adalah membangkitkan kembali vitalitas. Jadi, pengertian revitalisasi ini secara umum adalah usaha-usaha untuk menjadikan sesuatu itu menjadi penting dan perlu sekali. Maka dari itu yang akan menjadi bagian penting dalam aspek revitalisasi kali ini adalah komunikasi dalam kehidupan masyarakat urban/perkotaan.

Revitalisasi termasuk di dalamnya adalah konservasi-preservasi merupakan bagian dari upaya perancangan kota untuk mempertahankan warisan fisik budaya masa lampau yang memiliki nilai sejarah dan estetikaarsitektural. Kita sadari bahwa warisan yang dihadirkan kepada kita sebagai manusia tidak hanya berbentuk fisik tetapi juga kebudayaan yang diwariskan 
baik secara verbal ataupun non verbal. Menjadi penting juga jika kehidupan bergotong royong kita selalu diawali dengan komunikasi atau tepatnya merupakan upaya pelestarian lingkungan binaan agar tetap pada kondisi aslinya yang ada dan mencegah terjadinya proses kerusakan tatanan kehidupan bermasyarakat. Tergantung dari kondisi lingkungan binaan yang akan dilestarikan, maka upaya ini biasanya disertai pula dengan upaya restorasi, rehabilitasi dan/atau rekonstruksi. Jadi, revitalisasi adalah upaya untuk memvitalkan kembali suatu kawasan atau bagian kota yang dulunya pernah vital/hidup, akan tetapi kemudian mengalami kemunduran/degradasi. Untuk itu, tetap diperlukan perbaikan dan peningkatan aktivitas ekonomi (economic revitalization) yang merujuk kepada aspek sosial-budaya serta aspek lingkungan (environmental objectives). Hal ini mutlak diperlukan karena melalui pemanfaatan yang produktif, diharapkan akan terbentuklah sebuah mekanisme perawatan dan kontrol yang langgeng terhadap keberadaan fasilitas dan infrastruktur kota.

\section{Masyarakat Urban/Perkotaan}

Masyarakat urban/perkotaan adalah masyarakat kota yang tidak tertentu jumlah penduduknya. Masyarakat ini berarti juga dalam kehidupan sebuah komplek perumahan atau ruang lingkup yang memang memiliki ketersediaan fasilitas yang cukup, tekanan pada kata "kota", terletak pada sifat dan ciri kehidupan yang berbeda dengan masyarakat pedesaan (Fredian, 2014). Ada beberapa ciri masyarakat pada komunitas kota, yaitu: (1) kehidupan keagamaan berkurang bila dibandingkan dengan kehidupan agama di komunitas pedesaan, (2) warga komunitas kota pada umumnya dapat mengurus dirinya sendiri tanpa harus bergantung pada orang lain, (3) pembagian kerja di antara warga komunitas kota juga lebih tegas dan memiliki batas-batas nyata, (4) peluang kerja di komunitas kota lebih banyak, (5) jalan pikiran rasional umumnya dianut komunitas kota, (6) faktor waktu 
dinilai penting bagi komunitas kota, dan (7) perubahan social tampak nyata di komunitas kota. Dapat kita pahami juga semua ini menjadi pemicu yang terjadi tidak adanya komunikasi yang baik antar warga.

\section{Komunikasi}

Komunikasi adalah proses penyampaian pikiran atau perasaan oleh seseorang kepada orang lain dengan menggunakan lambang-lambang yang bermakna bagi kedua pihak, dalam situasi yang tertentu komunikasi menggunakan media tertentu untuk merubah sikap atau tingkah laku seorang atau sejumlah orang sehingga ada efek tertentu yang diharapkan (Effendy, 2000: 13). Dalam kehidupan komunikasi sering kali menjadi penentu jalan arah hidup seseorang menuju hal yang baik ataupun yang buruk. Melalui media petanque hendaknya nanti semua tersampaikan apa yang menjadi tujuan bersama untuk merevitalisasi masyarakat urban/perkotaan. Senada dengan apa yang telah disampaikan komunikasi merupakan proses pemindahan pengertian dalam bentuk gagasan, informasi dari seseorang ke orang lain (Handoko, 2002: 30).

Tidak ada kelompok yang dapat eksis tanpa komunikasi pentransferan makna di antara anggota-anggotanya. Hanya lewat pentransferan makna dari satu orang ke orang lain informasi dan gagasan dapat dihantarkan. Tetapi komunikasi itu lebih dari sekedar menanamkan makna tetapi harus juga dipahami (Robbins, 2003: 310).

Banyak orang tidak menyadari bahwa masalah-masalah yang dihadapi sebenarnya berasal dari komunikasi yang kurang baik. Salah satu yang menyebabkan timbulnya komunikasi tidak baik adalah karena komunikasi dengan diri sendiri tidak lancar atau bahkan tidak pernah diperhatikan (Meyer, 2015). Bagaimanapun juga, komunikasi dengan orang lain dipengaruhi oleh komunikasi dengan diri sendiri atau yang sering disebut dengan self-talk. Setiap bangun tidur, sebelum berkomunikasi dengan orang lain, komunikasi 
dengan diri sendiri sudah terlebih dahulu dilakukan. Oleh karena self-talk dilakukan setiap saat, maka jenis self-talk yang cenderung selalu dilakukan, apakah self-talk positif atau self-talk negatif, sangat penting untuk diperhatikan. Meyer (2005) menegaskan pentingnya self-talk, yaitu bagaimana berbicara kepada diri sendiri dan bagaimana berbicara tentang diri sendiri, baik dilakukan dalam hati ataupun diucapkan.

Berikut fungsi komunikasi menurut Robbins (2003: 310-311).

a. Kendali: komunikasi bertindak untuk mengendalikan prilaku anggota dalam beberapa cara, setiap organisasi mempunyai wewenang dan garis panduan formal yang harus dipatuhi oleh karyawan.

b. Motivasi: komunikasi membantu perkembangan motivasi dengan menjelaskan kepada para karyawan apa yang harus dilakukan bagaimana mereka bekerja baik dan apa yang dapat dikerjakan untuk memperbaiki kinerja jika itu di bawah standar.

c. Pengungkapan emosional: bagi banyak karyawan kelompok kerja mereka merupakan sumber utama untuk interaksi sosial, komunikasi yang terjadi di dalam kelompok itu merupakan mekanisme fundamental dengan mana anggota-anggota menunjukkan kekecewaan dan rasa puas mereka oleh karena itu komunikasi menyiarkan ungkapan emosional dari perasaan dan pemenuhan kebutuhan sosial.

d. Informasi: komunikasi memberikan informasi yang diperlukan individu dan kelompok untuk mengambil keputusan dengan meneruskan data guna mengenai dan menilai pilihan-pilihan alternatif.

Semua ini diharapkan menjadi bagian yang bisa terlaksana selama proses kegiatan perubahan cara masyarakat urban/perkotaan dalam menyikapi lingkungan social sekitarnya. 


\section{Petanque}

Pada Abad ke-6 SM, bangsa Yunani Kuno telah memainkan bentuk permainan Boules dengan alat koin, kepingan batu atau bola batu Pada Abad ke-9 SM, Penemuan alat permainan boules pada sebuah makam Mesir Purba yang berumur 7000 SM. Pada awal masehi, bangsa Romawi telah memainkan boules dengan bola kayu yang diberi paku-paku. Pada abad pertengahan, permainan petanque telah dimainkan di seluruh Eropa dikenal dengan sebutan boules. Pada abad ke-14, Raja Henri III dari Inggris, Raja Charles IV dan V melarang permainan Boules dan digantikan dengan bermain panah. petanque adalah olahraga yang diputar secara bertiga (triple) tetapi dapat juga dimainkan secara individu (single) atau berdua (double). Versi lain tidak diizinkan.

Petanque adalah olahraga baru bagi Indonesia yang dipertandingkan di SEA GAMES XXVI / 2011 di Palembang, Indonesia. Terbentuknya Federasi Olahraga Petanque Indonesia pada tanggal 18 Maret 2011. Berdirinya Venue Petanque di komplek olahraga Jakabaring yang representatif sebagai pusat pelatihan dan pembinaan. Pemanfaatan aset petanque pasca SEA GAMES. Berdasar dari semua ini kota Palembang yang menjadi tempat lahirnya petanque bisa dikatakan tidak banyak yang mengetahui. Hal ini menjadikan

peneliti sangat ingin memberikan ilmu pengetahuan yang luas terhadap masyarakat kota Palembang pada khususnya dan sumatera selatan pada umumnya. Selain daripada itu kita juga lebih mengenal petanque sebagai olahraga masyarakat dimana semua orang bisa ikut serta dan berpartisipasi dalam pelaksanaan kegiatannya. Petanque juga menjadikan aturan yang lebih sederhana dalam permainannya dan bisa menjadikan tempat berlatihnya dimanapun sekalipun didepan rumah yang memiliki kontur tanah beraspal. 


\section{Gambar 1. Bola Petanque}

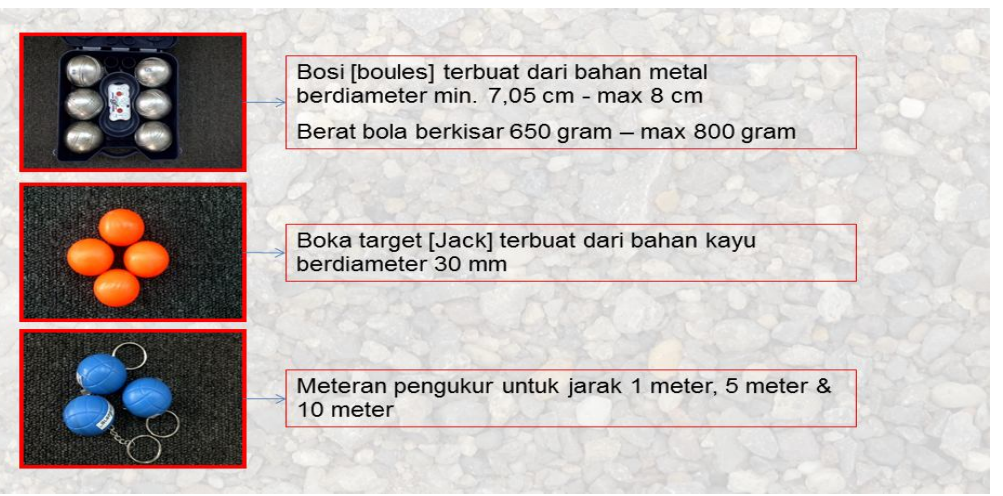

Beberapa Merk BOSI: OBUT - Perancis, LAFRANC - Thailand, Marathon - Thailand, JBPetanque - Perancis, Noere - Perancis, Integrale Perancis. Karena di Indonesia belum ada pabrik yang memproduksi bola petanque, maka bola petanque masih didapat dengan cara impor dari Thailand. Berdasarkan Peraturan FIPJP, standar lapangan petanque untuk kompetisi internasional dan nasional berukuran 15 meter x 4 meter. Petanque dapat dimainkan di atas tanah liat atau bebatuan, untuk lapangan rumput dan concrete tidak direkomendasi.

Petanque dapat dimainkan di permukaan rata pasir pantai, batu, tanah liat atau rumput, ukuran 15 meter x 4 meter atau minimal 12 meter x 3 meter, Berbentuk persegi panjang, apabila di lapangan luas diberi pembatas berupa tali dengan ukuran tersebut diatas.

Cara membangun lapangan tanah digali dengan kedalaman $150 \mathrm{~mm}$ s.d $200 \mathrm{~mm}$. Lapisan dasar diisi batu pecah, pecahan batu bata setebal 6-8 inci, lalu dipadatkan menjadi 4 inch. Lapisan tengah : di isi batu pecah sampai debu uk.1,5 inci, lalu dipadatkan dengan alat pemadat getar dengan bantuan penyiraman air dan di roll hingga rata. Pemasangan pembatas keliling lapangan terbuat dari kayu, conblock, beton setinggi 4 sampai dengan 6 inci. Lapisan atas atau permukaan ditabur batu pecah $1 / 4$ inci sampai debu diratakan keseluruh permukaan lapangan. Siap dimainkan (FOPI, 2011). 


\section{Revitalisasi Komunikasi Masyarakat Urban/Perkotaan Melalui Olahraga Petanque}

Seperti yang dikatakan Fredian (2014), bahwa masyarakat urban/perkotaan adalah warga komunitas kota yang pada umumnya dapat mengurus dirinya sendiri tanpa harus bergantung pada orang lain. Oleh karena itu dapat dipahami bahwa masyarakat perkotaan memiliki sifat individu yang tinggi, dapat juga kita pahami bahwa komunikasi antar sesama merupakan hal yang sangat jarang ditemukan didalam masyarakat urban/perkotaan. Oleh karena itu revitalisasi sosial sangat perlu dilakukan didalam pembentukan masyarakat urban/perkotaan yang sosialis. Kita memahami bahwa olahraga merupakan suatu aktivitas yang tidak dapat dipisahkan dari kehidupan manusia. Setiap kalangan masyarakat termasuk perkotaan juga pasti membutuhkan aktivitas olahraga, oleh karena itu olahraga dapat dijadikan sarana dalam kegiatan revitalisasi komunikasi antar masyarakat.

Petanque merupakan olahraga yang berasal dari prancis, yang menggunakan bola logam sebagai alatnya. Petanque dimainkan oleh dua hingga enam orang yang terbagi dalam dua tim, dan dimainkan dilapangan tanah atau lapangan berbatu namun harus datar (Galih, 2011). Dilihat dari karakteristik olahraga petanque, kita dapat memahamai bahwa karakteristik olahraga ini, cocok untuk dilakukan setiap kalangan masyarakat dikarenakan media dan tempat pelaksanaan mudah dicari. Di dalam suasana perkotaan yang sempit dan padat, olahraga petanque dapat dijadikan salah satu pilihan bagi masyarakat kota untuk tujuan rekreasi, kesehatan maupun kebugaran jasmani mereka. Kemudian Syafruddin (2013: 13) mengatakan bahwa olahraga rekreasi biasanya dilakukan setelah pekerjaan kantor, sekolah, penataran-penataran, dan lain sabagainya. Oleh karena itu kiranya petanque merupakan kegiatan yang cocok karakteristiknya dengan olahraga rekreasi.

Dengan diadakannya olahraga petanque ini didaerah perkotaan maka revitalisasi komunikasi antara masyarakat perkotaan dapat berjalan lebih 
efektif, hal ini dikarenakan setiap masyarakat khususnya kota pasti membutuhkan olahraga dan petanque merupakan olahraga yang cocok dilakukan didaerah perkotaan, kemudian dilihat dari karakerisitik permainan petanque ini membutuhkan dua orang atau lebih atau dengan kata lain akan terjadi komunikasi antar individu dan juga dapat dilakukan dimana saja asalkan datar.

\section{SIMPULAN DAN SARAN}

\section{Simpulan}

a. Masyarakat perkotaan cenderung bersifat individualis oleh karena itu perlu diadakan gerakan seperti revitalisasi yang bersifat komunikasi, agar hal ini dapat mengurangi dampak individualis lingkungan perkotaan.

b. Salah satu sarana yang tepat untuk revitalisasi komunikasi masyarakat urban/perkotaan adalah dengan melakukan aktivitas olahraga, hal ini dikarenakan setiap orang membutuhkan dan perlu melakukan aktivitas olahraga.

c. Olahraga petanque merupakan salah satu media yang efektif didalam revitalisasi komunikasi masyarakat urban/perkotaan, hal ini dikarenakan karakteristiknya yang umum dan juga dapat dijadikan kegiatan yang rutin.

\section{Saran}

a. Sebagai aktivitis yang bergerak dibidang sosial, komunikasi, dan olahraga membangun suatu gerakan komunitas merupakan hal yang perlu dilakukan, hal ini dikarenakan setiap individu memerlukan suatu pengetahuan untuk bersosialisasi.

b. Selain petanque masih banyak olahraga yang secara umum dapat dilakukan di lingkungan perkotaan, oleh karena itu dengan adanya ide atau gagasan ini dapat membuka pemikiran mengenai pemecahan masalah sosial didalam lingkungan perkotaan. 


\section{DAFTAR PUSTAKA}

Effendy, Onong Unchjana. 2000. Ilmu Komunikasi Teori dan Praktek. Bandung: Remaja Rosda Karya.

FOPI. 2011. Olahraga Petanque. Jakarta: PB. FOPI.

Fredian, T N. 2014. Pengembangan Masyarakat. Jakarta : Yayasan Pustaka.

Galih, Trendy. 2011. trendygalih.com/2011/11/olahraga-petanque/. Diakses tanggal 10 november 2017.

Handoko, T Hani. Manajemen. Yogyakarta: BPFE.

KBBI. 2005. Jakarta: Depkdiknas.

Meyer, Joyce. 2009. Never Give Up. New York: Faith Words.

Robbins, Stephen P. 2003. Perilaku Organisasi jilid I. Jakarta : Indeks Gramedia.

Syafruddin. 2013. Ilmu Kepelatihan Olahraga: Teori dan Aplikasinya dalam Pembinaan Olahraga. Padang: UNP Press.

Undang-undang Republik Indonesia No. 20 tahun 2003, Tentang Sistem Pendidikan Nasional. 